\title{
Analisa Penyebab Kerusakan Tanaman Cabai Menggunakan Metode K-Means
}

\author{
Darmansah* $^{* 1}$, Ni Wayan Wardani ${ }^{2}$ \\ ${ }^{1}$ Institut Teknologi Telkom Purwokerto; Jl. DI. Panjaitan No.128 Purwokerto, \\ Telp 0281-641629 \\ ${ }^{2}$ STMIK STIKOM Indonesia; Jl. Tukad Pakerisan No. 97 Panjer, Denpasar \\ e-mail: *11 darmansah@ittelkom-pwt.ac.id, ${ }^{2}$ niwayan.wardani@ stiki-indonesia.ac.id.
}

\begin{abstract}
Abstrak
Tanaman cabai merupakan komoditas pertanian yang dibutuhkan dalam kehidupan sehari hari, karena tanaman ini memiliki banyak kegunaan. Selain itu tanaman cabai merupakan tanaman yang bernilai ekonomis yang tinggi. Beberapa permasalahan dalam pengendalian penyakit dan hama antara lain adalah gejala awal yang tidak terlihat jelas sehingga petani maupun masyarakat sulit untuk mengelompokan penyebab kerusakan yang menyerang tanaman cabai sehingga mengakibatkan petani mengalami penurunan produksi panen bahkan menyebabkan gagal panen. Metode yang dipakai dalam menyelesaikan masalah ini yaitu Algoritma K-means. Algoritma K-Means clustering ini adalah sebuah metode yang berusaha mengelompokan data yang ada ke dalam beberapa kelompok, dimana data yang ada dalam satu kelompok mempunyai karakteristik yang sama satu sama lainnya dan mempunyai karakteristik yang berbeda dengan data yang ada dalam kelompok lain. Data cabai yang diolah dalam penelitian ini bersumber dari wilayah kerja Dinas Tanaman Pangan Hortikultura dan Perkebunan Provinsi Sumatera Barat dengan jumlah data sebanyak 11 buah. Selanjutnya data diolah menggunakan software rapidminer studio 7.6. Hasil dari pengujian terhadap metode ini terdapat tiga pengelompokan penyebab kerusakan pada tanaman yaitu CO untuk jenis cabai yang kerusakan sedang, Cl kerusakan berat dan C2 untuk kerusakan ringan. Kemudian hasil dari per cluster yaitu CO terdapat satu jenis hama yaitu Lalat Buah, C1 terdapat 3 jenis hama yang terdiri dari Virus kuning, Antraknose dan Thrips, sedangkan C2 terdapat 7 jenis hama yang terdiri dari Kutu Daun, Tungau, Layu Fusarium, Layu Bakeri, Virus Keriting, Mati Pucuk, Puru Buah. Analisa ini diharapkan memudahkan petani mengetahui penyebab kerusakan tanaman cabai atau dinas terkait bisa mengambil tindakan mengantisipasi penyebab penyebab kerusakan pada tanaman cabai secepat mungkin.
\end{abstract}

Kata kunci: Data Mining, Clustering, K-Means, Cabai.

\begin{abstract}
Pepper plants are agricultural commodities in need in everyday life today, because the plant has many uses. In addition, the chili plant is a plant that was a high economical value. Some of the problems in controlling diseases and pests, among others, are early symptoms that are not clearly visible so that farmers and communities find it difficult to detect the causes of damage that attacks the chilli plants, causing farmers to experience a decrease in crop production and even cause crop failure. The method used in solving this problem is the $K$ means Algorithm. This K-Means clustering algorithm is a method that attempts to classify existing data into several groups, where data in one group has the same characteristics with each other and has different characteristics from the data in other groups. Chilli data processed in this study was sourced from the working area of the Horticulture and Plantation Food Crops Office of West Sumatra Province with a total of 11 pieces of data. Furthermore, the data is processed using rapidminer studio 7.6 software. The results of the testing of this method there
\end{abstract}


are three grouping causes of damage to plants, namely CO for chili species with moderate damage, $C 1$ for heavy damage and $C 2$ for mild damage. Then the results of each cluster, namely $C O$ there is one type of pest, namely Fruit Fly, Cl there are 3 types of pests which consist of Yellow Virus, Anthracnose and Thrips, while C2 there are 7 types of pests consisting of aphids, mites, Fusarium wilt, Layu Bakeri, Curly Virus, Mati Pucuk, Puru fruit. This analysis is expected to make it easier for farmers to know the causes of damage to chili plants or related agencies can take action to anticipate the causes of damage to chili plants as quickly as

Keywords: Data Mining, Clustering, K-Means, Chili.

\section{PENDAHULUAN}

T anaman cabai adalah tanaman yang memiliki nilai ekonomis yang tinggi, selain itu tanaman cabai juga memiliki gizi yang baik untuk antoksidan. Dari penelitian sebelumnya ia mengatakan Tanaman cabai ialah salah satu jenis pertanian yang dibutuhkan dalam kehidupan sehari-hari, karena jenis tanaman ini memiliki banyak manfaat selain itu cabai merah merupakan tanaman hortikultura yang banyak digunakan untuk kebutuhan pangan [1]. Selain digunakan untuk salah satu bumbu masakan tanaman cabai ini juga memiliki kandungan kapsaikin, vitamin A, vitamin C, dan antioksidan. Antioksi bermanfaat untuk menambah daya tahan tubuh, melancarkan peredaran darah, menurunkan kadar kolestrol dan membantu proses pencernaan. Selain itu tanaman cabai merupakan tanaman yang bernilai ekonomi yang tinggi dan dapat menyebabkan inflasi Negara [2]. Terdapat beberapa masalah dalam membudidayakan cabai di lingkungan petani cabai yaitu sulitnya mendekteksi atau mengetahui gejala atau penyebab kerusakan pada tanaman cabai tersebut sehingga cabai bisa rusak seperti busuk, terserang hama dan bahkan gagal panen. Penelitian sebelumnya mengatakan beberapa kendala utama dalam pembudidayaan tanaman cabai adalah serangan hama atau penyakit. Penyakit atau hama sangat merugikan bagi petani sehingga membuat hasil panen menurun dan sampai gagal panen. permasalahan dalam pengendalian penyakit atau hama antara lain adalah gejala awal yang tidak terlihat jelas sehingga petani maupun masyarakat mengalamai kesulitan untuk megelompokan penyebab kerusakan tanaman cabai dari jenis hama atau penyakit yang menyerang tanaman dan identifikasi hama ataupun penyakit yang merusak tanaman, apabila penanganan lambat maka kerusakan tanaman akan semakin berat sehingga akan berakibat fatal bagi tanaman itu sendiri [2]. Banyak metode pendekatan yang dapat digunakan dalam menganalisa penyebab kerusakan pada tanaman cabai. Dari penelitian sebelumnya Metode yang bisa digunakan dari permasalahan di atas yaitu metode K-Means. Algoritma k-means adalah algoritma yang mempartisi data ke dalam cluster -cluster sehingga data yang memiliki kesamaan berada pada satu kelas atau kelompok yang sama dan data yang memiliki ketidak samaan berada pada kelas yang lain. Jadi dapat disimpulkan bahwa metode ini adalah pengelompokan data yang sama ke dalam satu cluster atau kelompok. Hal ini dianggap mampu untuk menganalisa suatu penyebab kerusakan tanaman dan diharapkan akan menghasilkan suatu pembelajaran yang mampu memberikan hasil yang optimal, sehingga dapat menentukan cara cara yang akan di antisipasi oleh masyarakat atau pihak terkait [3]. Untuk itu penulis ingin mencari solusi dari permasalahan ini yang dalam penelitian akan menggunakan sebuah metode yang bisa membantu Dinas Tanaman Pangan Hortikultura dan Perkebunan Provinsi Sumatera Barat dalam mengelompokan jenis jenis kerusakan tanaman cabai berdasarkan penyebab kerusakannya. Metode yang digunakan yaitu algoritma K-Means clustering yang berguna untuk mengelompokan tingkat kerusakan tanaman cabai yang terdiri dari kerusakan ringan, sedang dan berat. Kemudian seterusnya menguji dengan software Rapidminer. 


\section{LANDASAN TEORI}

\subsection{Knowledge Discovery in Database $(K D D)$}

Knowledge Discovery in Database (KDD) merupakan sebuah proses untuk menemukan pengetahuan yang berguna dalam sebuah basis data. Seluruh proses dari KDD biasanya terdiri dari beberapa tahapan -tahapan, yaitu yang pertama memahami bidang aplikasi, kedua membuat data target yang ditetapkan dari data mentah yang tersimpan dalam database, dan yang ketiga pembersihan data dan preprocessing data. Istilah knowledge discovery in data base atau mencari pengetahuan dalam sebuah basis dataatau bisa di singkat dengan istilah KDD, mengacu pada proses pencarian pengetahuan dalam data yang luas dan menekankan pada penerapan metode tingkat tinggi atau metode penambangan data tertentu. Ini menarik minat para peneliti dalam melakukan pengembang penelitian baik dalam bidang machine learning atau pembelajaran mesin [4].

\subsection{Data Mining}

Pendekatan Data Mining menjadi sangat penting dalam mengambil sebuah keputusan berdasarkan analisis dari data klinis yang besar. Data Mining berperan dalam proses penemuaninformasi yang tersimpandari dataset yang besar dan teknik-teknik seperti klasifikasi, pengelompokan, regresi dan asosiasi [4], pendapat lain mengatakan Data Mining merupakan gabungan dari beberapa bidang ilmu, antaranya yaitu basis data, information retrieval, statistik, machine learning dan sebagainya. Data Mining dapat diterapkan dibeberapa bidang, seperti bidang bisnis, kesehatan, asuransi, pemasaran dan perbankan. Data Mining merupakan bagian dari proses mencari pengetahuan dalam basis data (KDD) untuk menemukan informasi dan pola yang berguna dalam data [8], Data Mining merupakan kegiatan yang meliputi pengumpulan, pemakaian data historis untuk menemukan keteraturan, pola atau hubungan dalam data berukuran besar. Keluaran data mining ini bisa dipakai untuk membantu pengambilan sebuah keputusan di masa yang akan dating [6], Pendapat lain juga mengatakan bahwa Data merupakan sebuah metode pengolahan data berjumlah besar oleh karena itu Data Mining ini memiliki peranan penting dalam bidang industri, keuangan, cuaca, ilmu dan teknologi. Secara umum Data Mining membahas metode-metode seperti, pengelompokan, klasifikasi, regresi, seleksi variabel, dan market basket analisis [7].

\subsection{Clustering}

Pada dasarnya clustering merupakan suatu cara untuk mencari dan mengelompokkan data yang memiliki kesamaan karakter (similarity) antara satu data dengan data yang lain. Clustering merupakan salah satu metode Data Mining yang bersifat tanpa arahan (unsupervised), maksudnya metode ini diterapkan tanpa adanya latihan (training) dan tanpa ada guru (teacher) serta tidak memerlukan target keluaran [7], Klasterisasi (clustering) merupakan proses mengelompokkan objek berdasarkan informasi yang diperoleh dari data yang menjelaskan hubungan antar objek dengan prinsip untuk memaksimalkan kesamaan antar anggota satu kelas dan meminimumkan kesamaan antar kelas/cluster [8].

Dari penjelasan tersebut dapat penulis simpulkan bahwa clustering adalah proses pengelompokan objek berdasarkan informasi yang didapat dari data yang menjelaskan hubungan antar objek dengan prinsip untuk memaksimalkan kesamaan antar anggota satu kelas dan meminimumkan kesamaan antar kelas/cluster.

\subsection{Algoritma K-Menas}

Algoritma K-Means termasuk kedalam metode nonhierarchical yang mempartisi data kedalam bentuk satu atau lebih cluster kelompok, sehingga data yang mempunyai karakter yang sama dikelompokan dalam satu kelompok dan begitu sebaliknya [9]. Menurut pendapat lain 
mengatakan K-means adalah salah satu algoritma clustering yang menggunakan metode partisi.K-means adalah algoritma clustering yang membagi masing-masing item data ke dalam satu kelas yang sama [10]. K-Means clustering merupakan salah satu metode data clustering non-hirarki yang mengelompokan data dalam bentuk satu atau lebih cluster/kelompok. Datadata yang memiliki karakteristik yang sama dikelompokan dalam satu kelompok dan data yang memiliki karakteristik yang berbeda dikelompokan dengan kelompok yang lain sehingga data yang berada dalam satu cluster/kelompok memiliki tingkat variasi yang kecil [7].

Dari beberapa penjelasan diatas dapat penulis simpulkan bahwa algoritma K-Means adalah sebuah metode yang berusaha mengelompokan data yang ada ke dalam beberapa kelompok, dimana data yang ada dalam satu kelompok mempunyai karakter yang sama satu sama lainnya dan mempunyai karakter yang berbeda dengan data yang ada dalam kelompok lain.

\section{METODE PENELITIAN}

Metodologi penelitian merupakan suatu teknik untuk mencari atau mengumpulkan data primer atau sekunder yang akan digunakan untuk keperluan penelitian sebuah karya ilmiah, yang berhubungan dengan pokok permasalahan sehingga akan didapatkan suatu kebenaran data. Metodologi penelitian yang digunakan dalam penelitian ini yaitu analisis deskriptif kuantitatif di mana akan menggambarkan fakta dan informasi yang ada sehingga memberikan gambaran yang jelas mengenai penelitian yang dilakukan dengan menekankan pada data kuantitatif sebagai tolak ukur kajian.

\subsection{Merumuskan Masalah}

Pada tahap ini dilakukan penetapan perumusan masalah yang akan menjadi objek penelitian. Dengan menetapkan permasalahan yang ditemukan pada obyek yang diteliti guna mencari alternatif solusi yang terkait dengan permasalahan. Perumusan masalah dilakukan untuk memperoleh gambaran yang lengkap tentang lingkup masalah dan langkah yang tepat dalam pemecahannya serta membuat penelitian ini menjadi lebih terarah dan tidak mengambang.

\subsection{Studi Literatur}

Tahapan ini merupakan pengumpulan dan mempelajari literatur yang berkaitan dengan tujuan serta mendapatkan referensi pendukung yang memadai baik berupa jurnal penelitian maupun buku-buku mengenai algoritma $K$-Means dan software Rapidminer serta literatur yang membahas tentang data cabai untuk memperkuat pengetahuan dasar dan teori pendukung. Literatur dikumpulkan untuk memperkuat metode yang digunakan, dalam hal ini mengenai algoritma K-Means dan software RapidMiner.

\subsection{Menganalisa Data dengan Algoritma K-Means}

Pada tahap ini dilakukan analisa terhadap data cabai yang telah dikumpulkan berdasarkan rumus perhitungan yang ada. Data cabai yang telah diseleksi sebelumnya dimasukkan ke dalam rumus $K$-Means. Setelah dilakukan perhitungan maka akan didapat hasil dari data cabai tersebut.

\subsection{Menganalisa Data Menggunakan Aplikasi RapidMiner}

Tahapan selanjutnya adalah menggunakan RapidMiner untuk mengimplementasikan sistem yang telah dirancang, yaitu dengan menggunakan data cabai dari tahap sebelumnya. 
Dengan menggunakan RapidMiner penulis dapat menganalisa data cabai dengan menggunakan metode K-Means.

\subsection{Menguji Hasil}

Proses ini merupakan proses analisa untuk menguji apakah hasil pengolahan dan penghitungan yang dilakukan secara manual itu benar, maka selanjutnya dilakukan implementasi dengan menggunakan perangkat lunak dalam sistem aplikasi sehingga dapat dilihat perbandingan dan kesesuaian dari hasil keputusan akhir yang didapatkan dari sesi manual dengan menggunakan aplikasi RapidMiner.

\subsection{Menarik Kesimpulan}

Pada tahapan ini penulis dapat menarik kesimpulan dari penelitian ini, dimana kesimpulan ini dapat menjadi acuan bagi pihak yang ingin menggunakan hasil penelitian ini. Pada tahap ini juga dapat saran yang diberikan terkait dengan penelitian yang dilakukan ini.

\section{HASIL DAN PEMBAHASAN}

Berikut adalah hasil dan pembahasan pada penelitian penyebab kerusakan cabai menggunakan algoritma $K$-Means.

\subsection{Tranformasi Data}

Data trandormasi adalah data yang telah dipilih dari data set awal, karena tidak semua data yang di pakai dalam penelitian ini. Adapun data yang dipakai dapat dilihat pada tabel.1 di bawah ini:

Tabel 1. Tranformasi Data

\begin{tabular}{|c|c|c|c|}
\hline \multirow[t]{2}{*}{ Hama } & \multicolumn{3}{|c|}{$\begin{array}{c}\text { Luas keadaan serangan } \\
\text { (Ha) }\end{array}$} \\
\hline & Ringan & Sedang & Berat \\
\hline Virus Kuning & 8.95 & 1.85 & 0.50 \\
\hline Lalat Buah & 16.65 & 1.5 & 0 \\
\hline Antraknose & 11.32 & 0.45 & 0 \\
\hline Thrips & 8.64 & 1.2 & 0 \\
\hline Kutu Daun & 3.05 & 0 & 0 \\
\hline Tungau & 1.45 & 0 & 0 \\
\hline Layu Fusarium & 1.65 & 0 & 0 \\
\hline Layu Bakeri & 0.6 & 0 & 0 \\
\hline Virus Keriting & 0 & 0 & 0.25 \\
\hline Mati Pucuk & 0.25 & 0 & 0 \\
\hline Puru Buah & 1.3 & 0 & 0 \\
\hline
\end{tabular}

\subsection{Centroit Awal}

Merupakan nilai centroid awal yang ditentukan dalam pengolahan data penyebab kerusakan tanaman cabai. 
Tabel 2. Centroid Awal

\begin{tabular}{lccc}
\hline Penyebab & \multicolumn{3}{c}{ Luas keadaan serangan } \\
& $\begin{array}{c}\text { (Ha) } \\
\text { Ringan }\end{array}$ & Sedang & Berat \\
\hline $\begin{array}{l}\text { Lalat } \\
\text { Buah }\end{array}$ & 16.65 & 1.5 & 0 \\
\hline $\begin{array}{l}\text { Virus } \\
\text { Kuning }\end{array}$ & 8.95 & 1.85 & 0.50 \\
\hline $\begin{array}{l}\text { Layu } \\
\text { Fusarium }\end{array}$ & 1.65 & 0 & 0 \\
\hline
\end{tabular}

4.3 Menentukan Jarak Euclidean

$$
D_{(\mathrm{x}, \mathrm{y})}=\sqrt{(\mathrm{X} 1-\mathrm{Y} 1)^{2}+(X 2-Y 1)^{2}+. .+(X n-Y n)^{2}}
$$

Gambar 1. Rumus Menentukan Jarak Euclidean

$\mathrm{D}=$ Titik Dokumen

$\mathrm{X}=$ Data Record

$\mathrm{Y}=$ Data Centroid

$X_{1}=(8.95: 1.85: 0.50) \quad C_{0}=(16.65: 1.5: 0)$

$\mathrm{D}=\sqrt{(8.95-16.65)^{2}+(1.85-1.5)^{2}+(0.50-0)^{2}}$

$=7.7241$

begitu seterusnya sehingga di dapat hasil jarak euclidean seperti tabel 3 yang berikut ini:

Tabel 3. Nilai Jarak Euxclidean

\begin{tabular}{ccc}
\hline C 0 & C 1 & C 2 \\
\hline 7.7241 & 0 & 7.5473 \\
\hline 0 & 7.7241 & 15.0748 \\
\hline 5.4324 & 2.7976 & 9.6804 \\
\hline 8.0156 & 0.8766 & 7.0922 \\
\hline 13.6824 & 6.2034 & 1.4 \\
\hline 15.2738 & 7.7409 & 0.2 \\
\hline 15.0748 & 7.5473 & 0 \\
\hline 16.1199 & 8.5670 & 1.05 \\
\hline 16.7193 & 9.1426 & 1.6688 \\
\hline 16.4684 & 8.9085 & 1.4 \\
\hline 15.4231 & 7.8863 & 0.35 \\
\hline
\end{tabular}

4.4 Menentukan Letak Cluster

Langkah berikutnya yang dilakukan yaitu menentukan letak cluster atau menentukan letak kelompok kelompok datanya dengan cara membandingkan antara dua buah kelas, yaitu $\mathrm{C} 0, \mathrm{C} 1$, dan $\mathrm{c} 2$ disini nilai minimum merupakan nilai yang menjadi nilai pilihan. Jika ditemukan 
nilai yang paling kecil (minimum) maka dapat dimasukkan kedalam salah satu cluster tersebut. Untuk lebih jelas penulis telah memasukan data tersebut pada tabel.4;

Tabel 4. Penentuan Letak Cluster

\begin{tabular}{cccccc}
\hline C 0 & C 1 & C 2 & C0 & C1 & C2 \\
\hline 7.7241 & 0 & 7.5473 & & C1 & \\
\hline 0 & 7.7241 & 15.0748 & $\mathrm{C} 0$ & & \\
\hline 5.4324 & 2.7976 & 9.6804 & & $\mathrm{C} 1$ & \\
\hline 8.0156 & 0.8766 & 7.0922 & & $\mathrm{C} 1$ & \\
\hline 13.6824 & 6.2034 & 1.4 & & & $\mathrm{C} 2$ \\
\hline 15.2738 & 7.7409 & 0.2 & & $\mathrm{C} 2$ \\
\hline 15.0748 & 7.5473 & 0 & & $\mathrm{C} 2$ \\
\hline 16.1199 & 8.5670 & 1.05 & & $\mathrm{C} 2$ \\
\hline 16.7193 & 9.1426 & 1.6688 & & $\mathrm{C} 2$ \\
\hline 16.4684 & 8.9085 & 1.4 & & & $\mathrm{C} 2$ \\
\hline 15.4231 & 7.8863 & 0.35 & & & $\mathrm{C} 2$ \\
\hline & & & 1 & 3 & 7 \\
\cline { 3 - 5 }
\end{tabular}

\subsection{Hasil Perhitungan}

Berdasarkan perhitungan yang telah dilakukan dari jumlah data sebanyak 11 buah, dari tahapan pertama sampai akhir setelah tidak ada hasil yang berbeda dari iterasi kelompok pertama dengan iterasi ke dua dengen perhitungan algoritma k-means maka dapat di peroleh hasil nya sebagai berikut:

1. Cluster $0=1$ anggota

2. Cluster $1=3$ anggota

3. Cluster $2=7$ anggota

\subsection{Hasil Perhitungan Rapidminer}

Setelah proses manual tersebut selesai di lakukan maka langkah selanjut nya melakukan proses clusterig K-Means dengan apliaksi rapidminer studio 7.6. dengan jumlah sebanyak 11 buah. Adapun hasil nya dapat di lihat pada gambar 2.

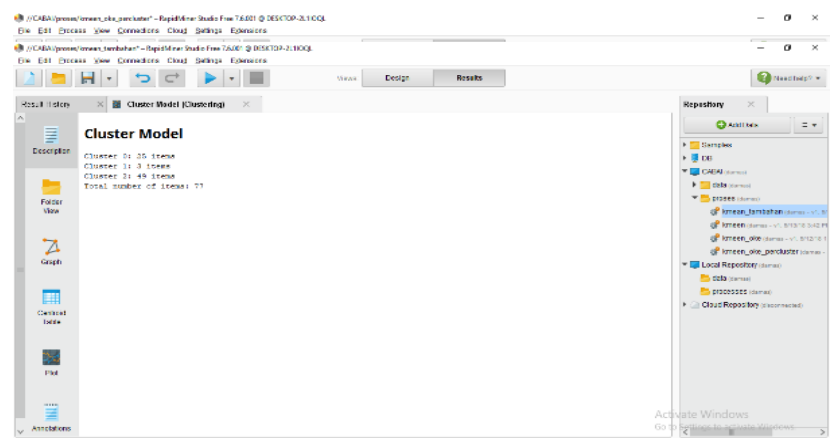

Gambar 2. Hasil Pengolahan dengan Rapidminer Studio 7.6

Hasil pengolahan dengan aplikasi ini dengan data yang sama maka hasilnya sama dengan pengolahan yang di lakukan secara manual. Sementara perhitungan yang di lakukan 
dengan jumlah data yang berbeda yaitu sebanyak 77 buah maka hasilnya yaitu Cluster $\mathrm{C} 0$ untuk kerusakan cabai berat terdapat 25 data yang terdiri dari 3 jenis penyebab kerusakan tanaman cabai, Cluster C1 untuk kerusakan cabai ringan terdapat 3 data yang terdiri dari 1 jenis penyebab kerusakan tanaman cabai, Cluster $\mathrm{C} 2$ untuk kerusakan cabai sedang terdapat 49 data yang terdiri dari 7 jenis penyebab kerusakan tanaman cabai.

\section{KESIMPULAN}

Berdasarkan hasil penelitian yang penulis lakukan dengan menggunakan metode $K$-Means penulis mendapat hasil dari jumlah data uji yang di olah sebanyak 11 data, maka didapat hasil setiap cluster yang ada $\mathrm{C} 0$ untuk mengambarkan atau menentukan kerusakan cabai yang berjenis sedang, $\mathrm{C} 1$ untuk menentukan kerusakan cabai yang berjenis berat, $\mathrm{C} 2$ untuk menentukan kerusakan cabai yang bejenis ringan. Untuk $\mathrm{C} 0$ terdapat 1 jenis penyebab kerusakan tanaman cabai yaitu Lalat Buah. Kemudian $\mathrm{C} 1$ terdapat 3 jenis penyebab kerusakan tanaman cabai yang terdiri dari Virus kuning, Antraknose dan Thrips, sedangkan untuk C2 terdapat 7 jenis penyebab perusakan tanaman cabai yang terdiri dari Kutu Daun, Tungau, Layu Fusarium, Layu Bakeri, Virus Keriting, Mati Pucuk, Puru Buah.

Setelah melakukan pengujian dengan aplikasi rapidminer studio 7.6. dengan jumlah data sebanyak 77 maka di dapat hasil untuk C0 menentukan kerusakan cabai berjenis berat yang terdiri dari 25 data, $\mathrm{C} 1$ untuk menentukan kerusakan cabai berjenis ringan sebanyak 3 data, sedangkan $\mathrm{C} 2$ untuk menentukan kerusakan cabai yang berjenis sedang terdapat 49 data.

\section{SARAN}

Adapun saran yang bisa penulis berikan pada penelitian berikut nya antara lain yaitu:

1. Penulis sangat menyarankan agar dilakukan penelitian atau pengembangan lebih lanjut terhadap penelitian penyebab kerusakan tanaman cabai dan membandingkan hasil metode ini dengan metode metode lainnya seperti metode Fuzzy C-Means, SelfOrganizing Map, K-Modes dan lain-lain.

2. Bagi pihak terkait baik itu petani maupun Dinas terkait dalam hal ini Dinas Tanaman Pangan Hortikultura dan Perkebunan Provinsi Sumatera Barat, agar aplikasi ini atau metode ini dapat diterapkan supaya pengelompokan data penyebab kerusakan tanaman cabai lebih cepat dan akurat, sehingga memudahakan untuk tindakan yang akan di lakukan.

3. Hasil dari proses data mining ini dapat digunakan sebagai pertimbangan dalam mengambil keputusan lebih lanjut tentang kebijakan yang di lakukan dinas pertanian dalam hal mengantisipasi persebaran penyebab kerusakan tanaman cabai, sehingga kualitas cabai semakin lebih baik.

\section{UCAPAN TERIMA KASIH}

Penulis ucapkan kepada semua pihak yang telah membantu demi terlaksananya penelitian ini yang tidak bisa penulis sebutkan namanya satu persatu. 


\section{DAFTAR PUSTAKA}

[1] M. Agen, H. Trichodermaharzianum, and D. A. N. Actinomycetes, "Supriati, L., dkk Pengendalian Penyakit Antraknosa pada ....," pp. 20-26, 2016.

[2] Y. A. Fitrianingtyas, C. Rahmad, T. Informatika, T. Informasi, and P. N. Malang, "Sistem Pakar Deteksi Hama dan Penyakit pada Tanaman Cabai dengan Metode Naïve Bayes, "Vol. 2015, pp. 68-72, 2015.

[3] N. Rohmawati W, Sofi. D, M. Jajuli "Implementasi Algoritma k- Pengklasteran Mahasiswa Pelamar Beasiswa" Jurnal Ilmiah Teknologi Informasi Terapan Volume I, No 2, 30 April 2015.

[4] A. Yudha F, Sarjon Defit, "P. Algoritma, K. Data, R. Medis, and C. Diseases", Jurnal Resti, Vol. 1, No. 2, pp. 82-89, 2017.

[5] C. Sari et al., "Clustering dan Visualisasi Data Magang Mahasiswa I-65 I-71 I-66 I72,”Vol. 9, pp. 71-76, 2017.

[6] L. Hakim and A. Fauzy, "Penentuan Pola Hubungan Kecelakaan Lalu Lintas Menggunakan Metode Association Rules dengan Algoritma Apriori,” pp. 73-81, 2015.

[7] J. O. Ong, "Implementasi Algotritma K-means Clustering untuk Menentukan Strategi Marketing President University," J. Ilm. Tek. Ind., Vol. 12, No, Juni, pp. 10-20, 2013.

[8] A. Fauzan, A. Y. Badharudin, F. Wibowo, J. Raya, and D. Purwokerto, "Sistem Klasterisasi Menggunakan Metode K-Means Dalam Menentukan Posisi Access Point Berdasarkan Posisi Pengguna Hotspot di Universitas Muhammadiyah Purwokerto Clustering System Using K-Means Method in Determining Access Point Position at Muhammadiyah Un," Vol. III, pp. 25-29, 2014.

[9] A. T. W. ; Rini A. Rahman, "Coal Trade Data Clusterung Using K-Means (Case Study PT . Global Bangkit Utama)," Vol. 6, No. 1, pp. 24-31, 2017.

[10] T. Khotimah, "Pengelompokan Surat Dalam Al Qur'an Menggunakan Algoritma KMeans," Simetris, Vol. 5, No. 1, pp. 83-88, 2014. 